\title{
Sistem Pengontrolan dan Keamanan Rumah Pintar (Smart Home) Berbasis Android
}

\author{
Dodon Yendri, Rahmi Eka Putri \\ Jurusan Sistem Komputer Fakultas Teknologi Informasi UNAND Padang 25163
}

\begin{tabular}{l} 
ARTICLE INFORMATION \\
Received: December 18, 2017 \\
Revised: February 12, 2018 \\
Available online: March 29, 2018 \\
KEYWORDS \\
\hline Raspberry Pi, sensor PIR, Smart Phone \\
CORRESPONDENCE \\
\hline Phone: (0751) 71181 \\
E-mail: dodon575@gmail.com
\end{tabular}

\begin{abstract}
A B S T $\mathbf{R}$ A $\mathbf{C}$ T
The tightness of one's activities sometimes makes people forget about security and comfort issues such as forgetting to lock the door, forgetting to turn off the lights or other electronic equipment so that it makes the house unsafe and also have an impact on energy waste. This research objective was to design a home security control system using Raspberry Pi connected to several electronic equipment, wifi, and internet communication networks. Remote control and monitoring using a smartphone. The test was carried out on ACS712 current sensor, PIR (Passive Infra Red) sensor, DHT22 temperature and humidity sensor, two lights and one webcam and buzzer. The test results show that the system that is designed can display information on current values, temperature, and humidity and also can control the condition of the house by turning on and off two lights with a $100 \%$ success rate. The PIR sensor can detect the movement of people at a maximum distance of 5.5 meters and the webcam manages to capture objects when motion is detected, the notification will automatically be sent to the owner's smartphone and the buzzer will be activated immediately.
\end{abstract}

\section{PENDAHULUAN}

Seringkali rumah ditinggal oleh penghuninya untuk bepergian seperti bekerja, ke sekolah, ke kantor ataupun keperluan lainnya. Rumah yang kosong penghuni pada umumnya kurang memiliki keamanan yang dapat diandalkan. Selain itu sebuah rumah terkadang kurang terjaga ketika para penghuni rumah sedang tidur dan beristirahat.

Padatnya kesibukan seseorang secara tidak sadar membuat orang menjadi lupa dengan hal-hal keamanan, seperti lupa mengunci pintu, lupa mematikan lampu ataupun peralatan elektronik yang sebenarnya tidak perlu hidup. Kelalaian seperti ini dapat menimbulkan kerugian besar yang berdampak terhadap pemborosan energi dan membengkaknya tagihan listrik, polusi bahkan berpotensi terjadinya resiko atau bencana. Sulitnya mengontrol hidup/mati lampu pada saat bepergian, kadangkala merepotkan tetangga dengan menitipkan kunci rumah agar dapat menghidupkan dan mematikan lampu pada saat meninggalkan rumah, tentunya dapat menimbulkan resiko keamanan dan beban sosial.

Perkembangan teknologi saat ini memungkinkan kita untuk melakukan berbagai macam hal. Raspberry $\mathrm{Pi}$, merupakan komputer berukuran sebesar kartu kredit, yang dapat dimanfaatkan sebagai pusat pengontrolan dan keamanan rumah secara otomatis yang disebut rumah pintar atau smart home.

\section{Rumah Pintar (Smart Home)}

Rumah pintar (smart home) adalah aplikasi gabungan antara teknologi dan pelayanan yang dikhususkan pada lingkungan rumah atau gedung dengan fungsi tertentu yang bertujuan untuk meningkatkan keamanan, efisiensi dan kenyamanan penghuninya. Sistem rumah pintar (smart home) biasanya terdiri dari perangkat monitoring, perangkat kontrol dan otomatis ada beberapa perangkat yang dapat di akses menggunakan komputer [1][2].

\section{Raspberry Pi}

Raspberry Pi merupakan single-board computer dengan ukuran kartu kredit yang dikembangkan di UK oleh Raspberry $P$ Foundation dengan tujuan untuk mendorong ilmu komputer di berbagai sekolah [3].

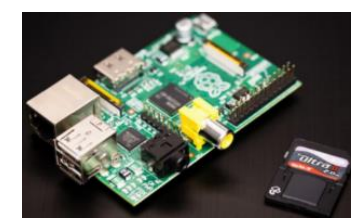

Gambar 1. Raspberry Pi Model B [3]

Raspberry Pi memiliki system on a chip (SoC) Broadcom BCM2835. SoC merupakan sebuah IC yang mengintegrasikan 
semua komponen dari sebuah komputer seperti CPU, GPU, RAM menjadi satu IC. SoC Broadcom BCM2835 ini mempunyai prosesor ARM1176JZF-S dengan kecepatan $700 \mathrm{MHz}$ yang dapat ditingkatkan (overclock) menjadi $1 \mathrm{GHz}$. SoC ini juga dilengkapi dengan Video Core IV GPU dan RAM sebanyak 512 MB untuk model B dan 256 MB untuk model A.

\section{Sensor PIR}

Sensor PIR (Passive Infra Red) adalah sensor yang digunakan untuk mendeteksi adanya pancaran sinar infra merah. Sensor PIR bersifat pasif, artinya sensor ini tidak memancarkan sinar infra merah, tetapi menerima radiasi sinar infra merah dari luar. Sensor ini biasanya digunakan dalam perancangan detektor gerakan. Karena semua benda memancarkan energi radiasi, sebuah gerakan akan terdeteksi ketika sumber infra merah dengan suhu tertentu. Gambar 2 berikut memperagakan sebuah diagram sensor PIR[5].

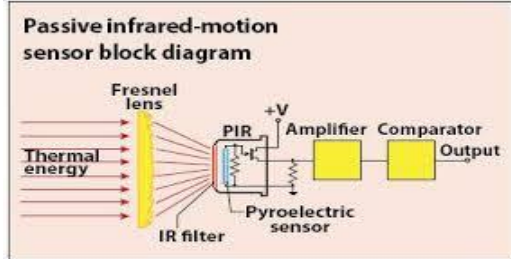

Gambar 2 Diagram Sensor PIR

Radiasi infra merah akan ditangkap melalui Fresnel lens yang kemudian disaring oleh IR Filter agar hanya gelombang infra merah dari manusia saja yang dideteksi oleh sensor, yaitu antara 8 sampai $14 \mu \mathrm{m}$. Radiasi infra merah yang sudah disaring ini kemudian ditangkap oleh pyroelectric sensor, yakni sebuah sensor yang terbuat dari provinil florida (PVF). Pyroelectric sensor ini akan menghasilkan arus listrik ketika mendapatkan radiasi infra merah.

\section{Sensor DHT22}

Sensor DHT22 merupakan sensor suhu dan kelembaban dasar dengan input digital. Sensor ini dapat mengukur suhu dan kelembaban dengan membaca kondisi udara disekitar, bekerja pada tegangan 5V DC serta memiliki akurasi, ketajaman pembacaan dan jangkauan yang lebih jika dibandingkan dengan LM35 ataupun DHT11.

\section{Sensor ACS712}

Sensor ACS712 berfungsi untuk mendeteksi arus listrik baik AC ataupun DC dalam sebuah pengkabelan listrik, dan menghasilkan sebuah sinyal yang proporsional sesuai dengan hasil deteksi. Sinyal yang dihasilkan dapat berupa analog maupun digital. Sensor ini dapat dirancang untuk menghasilkan tampilan dari arus listrik yang diukur sehingga dapat disimpan sebagai data untuk analisa lebih jauh dalam sebuah sistem akuisisi data atau dapat digunakan untuk tujuan pengontrolan.

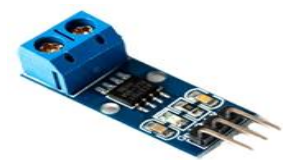

Gambar 3. Sensor ACS712

\section{Relay Module}

Relay Module merupakan sebuah piranti yang menggunakan elektromagnet untuk mengoperasikan seperangkat kotak sakelar. Susunan paling sederhana terdiri dari kumparan kawat penghantar yang dililit pada inti besi. Bila kumparan ini diberi energi, medan magnet yang terbentuk menarik poros yang digunakan sebagai pengungkit mekanisme sakelar magnet.

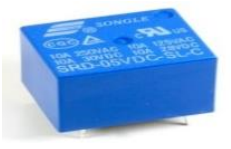

Gambar 4. Relay

\section{WebCam}

Webcam singkatan dari web dan camera, merupakan sebutan kamera real-time yang gambarnya dapat di lihat secara langsung online melaului internet. Webcam adalah sebuah kamera video digital kecil yang dihubungkan ke komputer dan biasanya melalui colokan USB atau pun colokan PORTCOM. Pada umumnya webcam tidak membutuhkan kaset atau tempat penyimpanan data. Data hasil perekaman yang didapat langsung ditransfer ke komputer.

Webcam bekerja seperti sebuah kamera digital hanya saja webcam ini di disain untuk komputer. Jadi tidak bisa di bawa ke mana-mana dan jauh lebih simple di banding dengan kamerakamera pada umumnya, yang diperlihatkan pada gambar 5 .

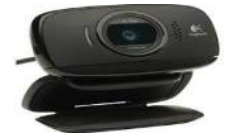

Gambar 5. WebCam

\section{Buzzer}

Buzzer adalah suatu alat yang dapat mengubah sinyal listrik menjadi sinyal suara. Pada umumnya buzzer digunakan sebagai alarm, karena penggunaannya cukup mudah yaitu dengan memberikan tegangan input maka buzzer akan mengeluarkan bunyi. Frekuensi suara yang dikeluarkan oleh buzzer yaitu antara $1-5 \mathrm{KHz}$.

\section{Smart Phone}

Smart phone digunakan untuk mendeskripsikan suatu mobile device yang menggabungkan sebagian besar fungsi yang dimiliki oleh sebuah mobile phone, Personal Digital Assistant (PDA), dan Personal Computer (PC). Smart phone juga menyediakan berbagai fitur yang lebih canggih dari pada mobile phone seperti teknologi touch screen, portable media player, Global Positioning System (GPS), QWERTY keyboard dan Wireless Fidelity (Wi-Fi). Setiap smart phone memiliki sistem operasi seperti halnya pada komputer. Beberapa jenis sistem operasi pada smart phone adalah iPhone OS(iOS), Android, dan Symbian [6].

\section{Android}

Android merupakan sistem operasi yang perkembangannya sangat masif dan cepat. Saat ini android sudah identik dengan smart phone. Perkembangan aplikasi di android juga sangat cepat, bahkan tahun 2010 tiap bulan ada lebih dari 10 ribu aplikasi ditambahkan untuk android. Android adalah sebuah sistem 
operasi untuk perangkat mobile berbasis linux yang mencakup sistem operasi middle ware dan aplikasi. Android tidak hanya menjadi sistem operasi di smart phone, bahkan android menjadi pesaing utama dari Apple pada sistem operasi Tablet PC[6]. Android merupakan sebuah perangkat mobile yang berbasis linux yang bersifat open source sehingga memudahkan pengembang untuk menciptakan aplikasi mereka sendiri.

\section{METODOLOGI PENELITIAN}

Metode Penelitian ini menggunakan studi literatur dan penelitian eksperimen. Studi literatur diperlukan untuk mendapatkan sumber bacaan seperti teori dasar, jurnal atau referensi lain yang digunakan dalam penelitian sedangkan untuk mengimplementasikannya menggunakan metode penelitian eksperimen.

Penelitian pengontrolan dan keamanan rumah pintar ini mengimplementasikan beberapa komponen seperti sensor ACS712, sensor DHT22, sensor PIR, relay module dan webcam yang terhubung ke Raspberry Pi sebagai pusat pengontrolan. Gambar 6. merupakan gambaran secara umum sistem rumah pintar (smart home) yang dibangun.

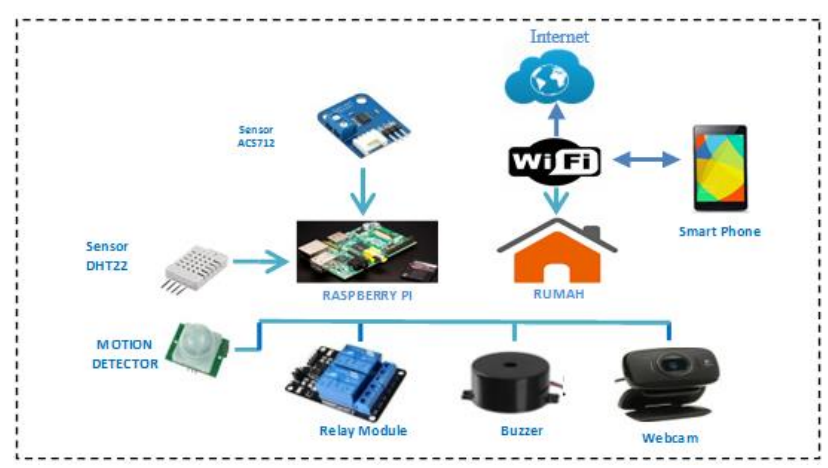

Gambar 6. Gambaran Secara Umum Sistem Smart Home

Dari gambar 6 dapat dijelaskan bahwa sistem akan mengontrol semua aktifitas yang ada di dalam rumah. Sebagai pusat pengontrolan, Raspberry Pi memiliki fitur yang lebih lengkap dibandingkan dengan pengontrolan lain, diantaranya dapat berfungsi sebagai Web Server. Data hasil pembacaan sensor dan Webcam kemudian diteruskan ke Raspberry Pi untuk dilakukan pengolahan. Hasil pengolahan pada Raspberry Pi dikirimkan langsung ke media output melalui wifi dan internet seperti smart phone, buzzer Apabila ada gerakan objek yang terdeteksi oleh sensor PIR, maka kamera akan meng-capture objek dan buzzer akan aktif seketika.

\section{Perancangan Sistem}

Berdasarkan rancangan umum pemodelan rumah pintar pada gambar 6 diatas, selanjutnya dilakukan perancangan sistem yang akan dibangun. Kegiatan awal dari perancangan sistem adalah melakukan analisis dan penentuan kebutuhan sistem, kemudian dilanjutkan dengan perancangan perangkat keras untuk membangun komponen-komponen yang digunakan dan perancangan perangkat lunak untuk membaca sistem.

\section{Perancangan Perangkat Keras}

Sistem pengontrolah rumah pintar (smart home) dibangun menggunakan beberapa komponen perangkat keras. Adapun diagram blok sistem perangkat keras yang digunakan dapat dilihat pada gambar 7 .

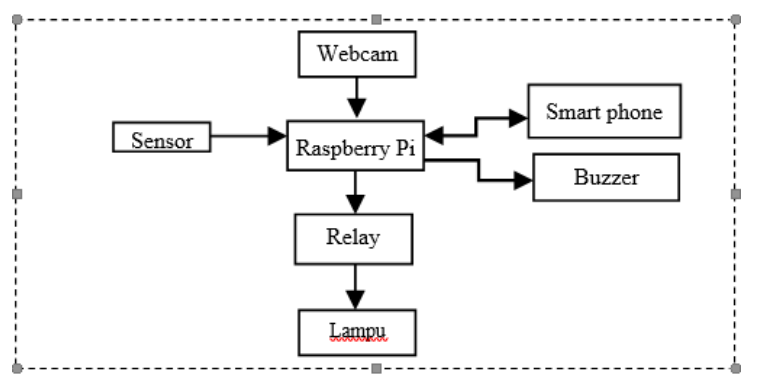

Gambar 7. Diagram Blok Sistem Perangkat Keras

Dari gambar 7 dapat dijelaskan fungsi dari masing-masing blok sebagai berikut:

1. Sensor digunakan untuk membaca data lingkungan yang terdiri dari sensor DHT22, PIR dan ACS712.

2. Raspberry $\mathrm{Pi}$ bertugas mengontrol peralatan lampu melalui relay sesuai perintah.

3. Relay adalah perangkat yang bertugas untuk mengatur menghidupkan dan mematikan lampu sesuai yang diperintahkan Raspberry $\mathrm{Pi}$

4. Webcam digunakan untuk meng-capture objek apabila ada gerakan yang terdeteksi.

5. Smart Phone penerima notifikasi dari Raspberry Pi apabila sensor PIR mendeteksi adanya gerakan.

6. Buzzer sebagai output apabila ada gerakan terdeteksi.

\section{Perancangan Perangkat Lunak}

Informasi pemantauan suhu, kelembaban dan pemakaian arus dilakukan menggunakan bahasa pemrograman Python pada Raspberry Pi. Sedangkan untuk user interface menggunakan bahasa PHP. Secara umum perancangan perangkat lunak dapat digambarkan dalam bentuk flowchart seperti terlihat pada Gambar 8.

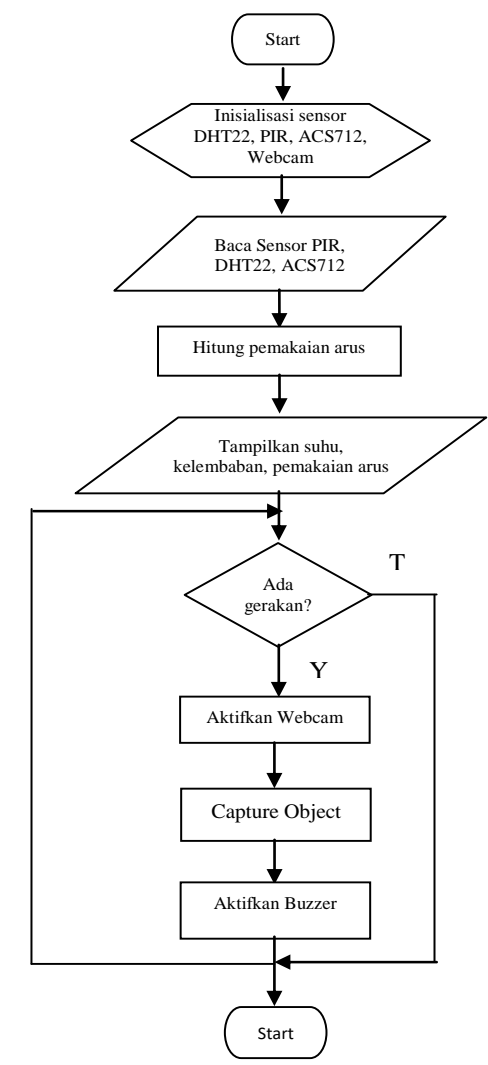

Gambar 8. Flowchart Pembacaan Sensor 
Berdasarkan gambar 8 dapat jelaskan bahwa, pertama-tama isinialisasi komponen dan sensor yang digunakan, yakni sensor suhu dan kelembaban DHT22, sensor gerakan PIR, sensor arus ACS712 dan Webcam. Sensor DHT22, sensor PIR dan sensor ACS712 akan bekerja sesuai dengan fungsinya yakni membaca suhu dan kelembaban, mendeteksi adanya gerakan, serta menghitung arus dalam sebuah pengkabelan listrik.

Hasil pembacaan sensor diteruskan pada Raspberry Pi untuk dilakukan pengolahaan. Selanjutnya sistem akan menampilkan informasi pembacaan suhu dan kelembaban, informasi pemakaian arus pada smart phone pemilik rumah yang sudah diset terlebih dahulu. Apabila hasil pembacaan sensor PIR mendeteksi adanya gerakan, maka webcam akan diaktifkan untuk meng-capture objek disekitar dan buzzer akan berbunyi seketika. Sistem juga dapat menghidupkan dan mematikan peralatan elektronik melalui smart phone pemilik rumah.

\section{HASIL DAN PEMBAHASAN}

Sistem rumah pintar (smart home) dibangun dengan menghubungkan beberapa komponen dengan Raspberry Pi sebagai pusat pengontrolan. Adapun hasil perancangan perangkat keras atau mekanik sistem yang dibangun adalah seperti terlihat pada gambar 9 .

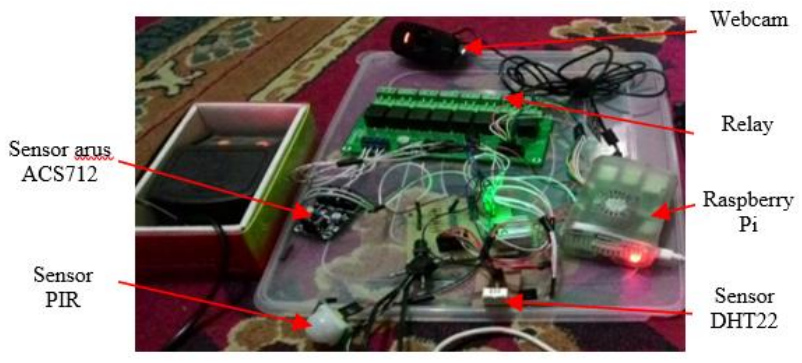

Gambar 9. Mekanik Sistem

Dari beberapa komponen yang digunakan, semua komponen dapat bekerja sesuai dengan fungsinya masing-masing. Hal ini dapat dilihat dari pengimplementasiannya menggunakan perangkat lunak yang dibangun. Supaya data dapat dikirimkan dari web server ke smart phone, dan smart phone dapat menerima notifikasi dan mengakses sistem untuk pengontrolan peralatan seperti mematikan dan menghidupkan lampu, dilakukan terlebih dahulu dengan memasukkan nama Service Set Identifier (SSID) dari wireless network, IP dari web server dan API Key ke dalam program Raspberry $P$.

\section{Pengujian Sensor Arus ACS712 dan Sensor Suhu DHT22}

Sensor arus ACS712 dan sensor suhu DHT22 sudah dapat bekerja dengan baik dan sesuai dengan kebutuhan. Pembacaan sensor arus hanya dibatasi pada arus yang mengalir pada perangkat (lampu) yang terhubung dengan relay. Pada penelitian ini sensor arus yang digunakan adalah ACS712 dengan arus 5V. Sensor arus ACS712 dapat mengukur arus positif dan negatif dengan kisaran -5A sampai 5A yang memerlukan suplai daya sebesar 5V. Untuk membaca nilai tengah (nol Ampere) tegangan sensor diset pada $2.5 \mathrm{~V}$ yaitu setengah kali tegangan sumber daya $\mathrm{VCC}=5 \mathrm{~V}$. Hasil pembacaan sensor arus dan sensor suhu dapat dilihat pada gambar 10 .

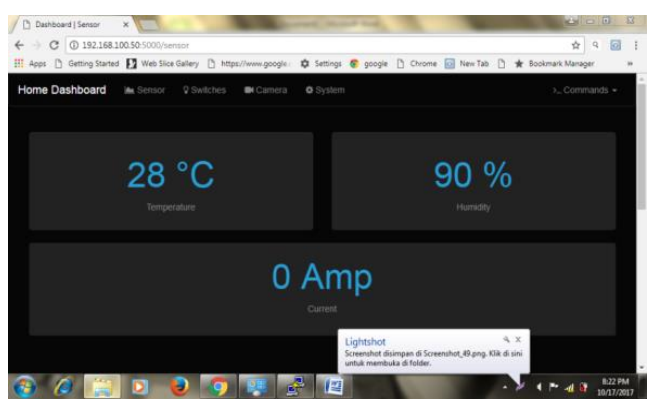

Gambar 10 Hasil Pembacaan Sensor ACS712 dan DHT22

Gambar 10 menampilkan hasil pembacaan sensor suhu DHT22 dengan keluaran suhu sebesar $28^{\circ} \mathrm{C}$ dan kelembaban sebesar $90 \%$, serta sensor arus ACS712 dengan keluaran 0 Amp. Untuk melakukan pengontrolan peralatan dengan daya yang lebih besar, dapat menggunakan sensor arus dengan kapasitas yang lebih besar dengan presisi yang lebih tinggi sehingga dapat dipasang pada PCB untuk mengontrol semua peralatan elektronik yang ada di dalam rumah

\section{Pengujian Rangkaian Relay}

Relay sudah bekerja dengan baik untuk pengontrolan peralatan dengan daya kecil dan sudah mampu menghidupkan dan mematikan peralatan elektronik. Pengujian menghidupkan dan mematikan lampu menggunakan smart phone dapat dilihat pada gambar 11 dan gambar 12 .

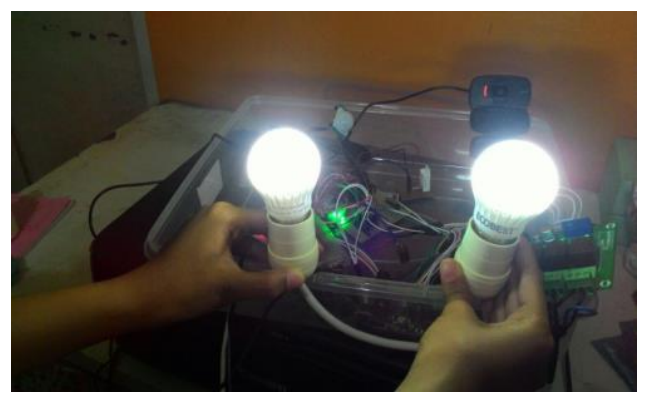

Gambar 11. Sistem menghidupkan dua lampu menggunakan Relay

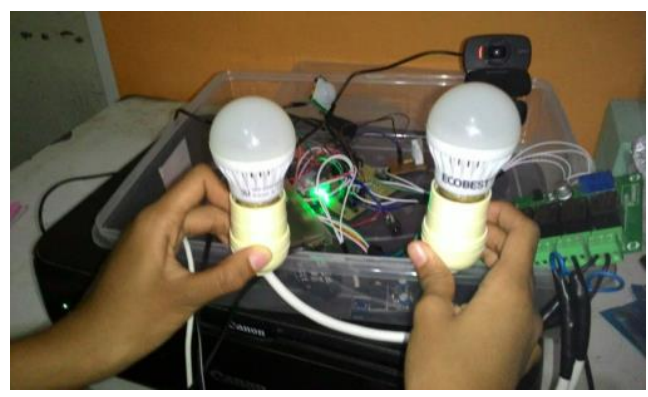

Gambar 12. Sistem mematikan dua lampu menggunakan Relay

Pengujian menghidupkan dan mematikan lampu dari smart phone dilakukan lima kali percobaan untuk masing-masing dengan hasil yang ditunjukkan pada Tabel 1. 
Tabel 1 Pengujian menghidupkan dan mematikan lampu

\begin{tabular}{|l|c|c|c|}
\hline \multirow{2}{*}{ Jenis Peralatan } & $\begin{array}{c}\text { Pengujian } \\
\text { ke }\end{array}$ & \multicolumn{2}{|c|}{ Kondisi } \\
\cline { 2 - 4 } & & On & Off \\
\hline Lampu 1 & 1 & Menyala & Mati \\
\cline { 2 - 4 } & 2 & Menyala & Mati \\
\cline { 2 - 4 } & 3 & Menyala & Mati \\
\cline { 2 - 4 } & 4 & Menyala & Mati \\
\hline Lampu 2 & 5 & Menyala & Mati \\
\cline { 2 - 4 } & 2 & Menyala & Mati \\
\cline { 2 - 4 } & 3 & Menyala & Mati \\
\cline { 2 - 4 } & 4 & Menyala & Mati \\
\cline { 2 - 4 } & 5 & Menyala & Mati \\
\hline
\end{tabular}

Dari pengujian seperti terlihat pada Tabel 1 menunjukkan bahwa smart phone berhasil 100\% menghidupkan dan mematikan dua buah lampu. Namun untuk keamanan dengan mengontrol berbagai macam peralatan elektronik dirumah tangga, sebaiknya menggunakan relay dengan kapasitas besar dengan presisi tinggi.

\section{Pengujian Sensor PIR, Kamera dan Buzzer}

Motion sensor (sensor PIR) sudah dapat mendeteksi gerakan dengan baik, namun pada pembacaan gerakan sebelum dan sesudah deteksi masih terdapat delay beberapa milli second. Kamera berhasil me-capture objek sesuai dengan fungsinya. Begitu juga dengan buzzer sudah berfungsi dengan baik, sehingga dapat menghasilkan bunyi apabila terdeteksi adanya gerakan dan webcam menangkap objek. Gambar 12. memperlihatkan sensor PIR mendeteksi gerakan dan sekaligus sistem mengirim notifikasi ke smart phone, gambar 13. kamera mengcapture saat itu juga sekaligus alarm akan berbunyi.

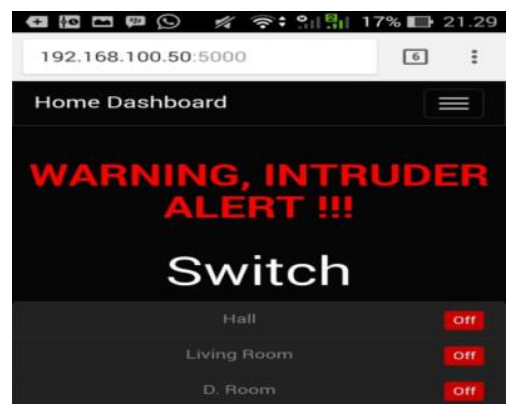

Gambar 12. Sensor PIR mendeteksi gerakan dan notifikasi diterima smart phone

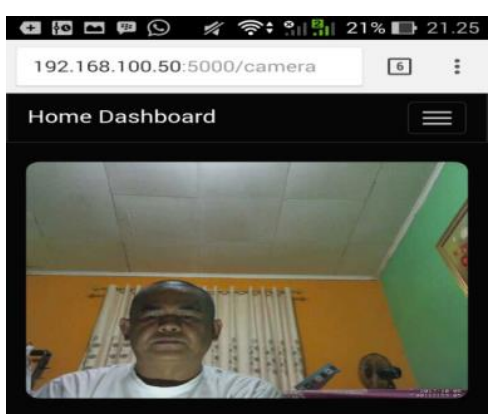

Gambar 13. Kamera melakukan capture objek

Dari beberapa kali pengujian terhadap komponen sensor PIR, Webcam, Buzzer dan notifikasi pada Smart Phone pada jarak 0.5 sampai dengan 6.5 meter dapat dilihat hasilnya pada Tabel 2 .
Tabel 2 Pengujian Sensor PIR, Webcam dan nottifikasi pada Smart Phone

\begin{tabular}{|c|l|l|l|l|}
\hline $\begin{array}{c}\text { Jarak } \\
(\mathbf{m})\end{array}$ & Sensor PIR & Webcam & Buzzer & $\begin{array}{c}\text { Notifikasi } \\
\text { pada } \\
\text { Smart } \\
\text { Phone }\end{array}$ \\
\hline 0.5 & Terdeteksi & Ter-capture & Aktif & Terkirim \\
\hline 1.0 & Terdeteksi & Ter-capture & Aktif & Terkirim \\
\hline 1.5 & Terdeteksi & Ter-capture & Aktif & Terkirim \\
\hline 2.0 & Terdeteksi & Ter-capture & Aktif & Terkirim \\
\hline 2.5 & Terdeteksi & Ter-capture & Aktif & Terkirim \\
\hline 3.0 & Terdeteksi & Ter-capture & Aktif & Terkirim \\
\hline 3.5 & Terdeteksi & Ter-capture & Aktif & Terkirim \\
\hline 4.0 & Terdeteksi & Ter-capture & Aktif & Terkirim \\
\hline 4.5 & Terdeteksi & Ter-capture & Aktif & Terkirim \\
\hline 5.0 & Terdeteksi & Ter-capture & Aktif & Terkirim \\
\hline 5.5 & Terdeteksi & Ter-capture & Aktif & Terkirim \\
\hline 6.0 & $\begin{array}{l}\text { Tdk.Terdet } \\
\text { eksi }\end{array}$ & $\begin{array}{l}\text { Tdk.ter- } \\
\text { capture }\end{array}$ & Tdk.Aktif & Tdk.Terkirim \\
\hline 6.5 & $\begin{array}{l}\text { Tdk.Terdet } \\
\text { eksi }\end{array}$ & $\begin{array}{l}\text { Ttdk.ter- } \\
\text { capture }\end{array}$ & Tdk.Aktif & Tdk.Terkirim \\
\hline
\end{tabular}

Dari pengujian yang dihasilkan pada Tabel 2 dapat dilihat bahwa pada saat sensor PIR mendeteksi gerakan, webcam langsung meng-capture objek, buzzer aktif seketika dan notifikasi terkirim pada smart phone dengan jarak maksimal 5.5 meter pada sudut $0^{\circ}$. Untuk mendapatkan hasil yang lebih akurat dapat dikembangkan dengan menggunakan sensor gerak microwave radar switch yang memanfaatkan gelombang microwave, sehingga pembacaan lebih akurat dan stabil tanpa adanya delay. Begitu juga dengan webcam, karena webcam yang digunakan bersifat statis, maka peng-capture-an tidak dapat dilakukan kemana arah gerakan terjadi. Untuk pengembangan selanjutnya sebaiknya menambahkan motor servo atau menggunakan IP Camera yang memiliki auto- tracking.

\section{Pengujian User Interface Sistem}

Perangkat lunak dibangun dengan menggunakan bahasa pemrograman Phyton untuk membaca sensor dan komponen, sedangkan untuk menampilkan user interface digunakan pemrograman PHP. Berikut gambar 14 dan gambar 15.merupakan tampilan sistem saat pertama kali diaktifkan pada laptop dan smart phone.

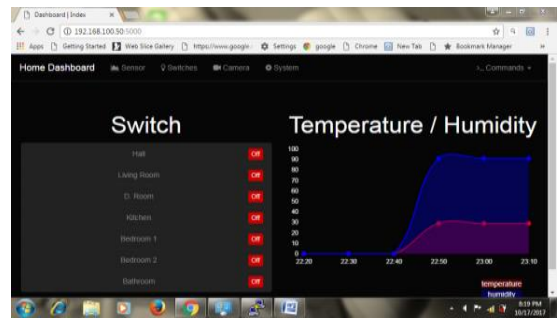

Gambar 14. Tampilan utama sistem Smart Home pada Laptop

Pada gambar 14 terlihat bahwa sistem rumah pintar terdiri atas menu Dashbord, Sensor, Switch, Camera dan System. Menu Dashboard adalah untuk menampilkan layar utama dari sistem yang dirancang dan terdiri dari informasi temperature dan kelembaban serta menampilkan button untuk pengontrolan switch lampu. Sub menu Sensor untuk menampilkan hasil pembacaan sensor, Switch untuk menampilkan Button menghidupkan dan mematikan lampu, Web Cam untuk menampilkan pembacaan kamera dan System untuk menampilkan penggunaan sistem 
seperti hostname, IP Address, OS, penggunaan memory, temperature CPU. Dapat dilihat bahwa sensor suhu dan kelembaban dapat bekerja dengan baik.

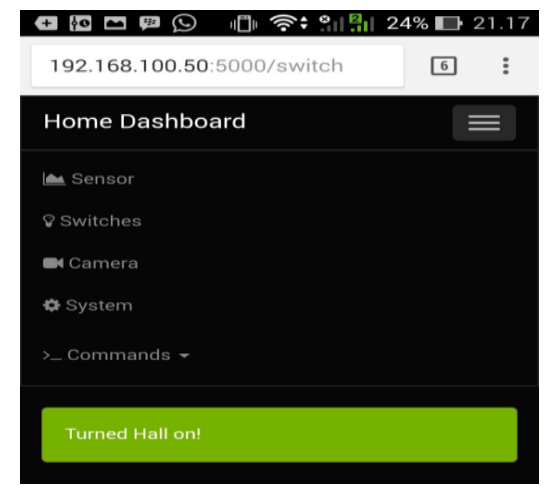

Gambar 15. Tampilan utama sistem pada Smart Phone

Dari gambar 15 terlihat karena keterbatasan layar smart phone, hanya sebahagian yang ditampilkan sesuai ukurannya, namun cara kerja dari sistem sama.

\section{KESIMPULAN}

Dari penelitian yang sudah dilakukan dapat disimpulkan bahwa sistem pengontrolan dan keamanan rumah pintar (smart home) berbasis Android menggunakan Raspberry Pi telah berhasil dibangun, dimana sistem dapat menghidupkan dan mematikan lampu melalui smart phone dengan tingkat keberhasilan 100\%, sensor PIR dapat menteksi gerakan, webcam dapat meng-capture objek dan sistem mengirimkan notifikasi ke smart phone maksimal pada jarak 5,5 meter dan buzzer dapat aktif seketika pada saat gerakan terdeteksi. Selain itu, sistem dapat menampilkan informasi suhu, kelembaban dan pemakaian arus pada smart phone.

\section{ACKNOWLEDGMENT}

Dalam melaksanakan penelitian ini, penulis banyak mendapat bantuan dan arahan dari berbagai pihak. Terima kasih saya ucapkan kepada Bapak DR. Ahmad Syafruddin Indraprayitna, MT. selaku Dekan Fakultas Teknologi Informasi Universitas Andalas yang telah memberikan kesempatan kepada penulis untuk melakukan penelitian, Bapak DR. Rika Ampuh Hadiguna, MT., yang telah memberikan arahan dalam pelaksanaan penelitian, serta Handra Romel, S.Kom yang telah banyak membantu penulis secara teknis dalam melakukan penelitian ini.

\section{DAFTAR PUSTAKA}

[1] Yurmama, Fajar, Tri. 20 Juni 2009. "Perancangan Software Aplikasi Pervasive Smart Home", (Online), (http://journal.uii.ac.id/index.php/Snati/article/view/1239/1 039. Diakses 15 Juli 2017).

[2] Masykur, Fauzan dan Prasegiowati, 2016, P., Aplikasi Rumah Pintar (Smart Home) Pengendali Peralatan Elektronik Rumah Tangga Berbasis Web, Jurnal Teknologi Informasi dan Ilmu Komputer (JTIIK) Vol. 3, No. 1, Maret 2016, hlm. 51-58.
[3] Richardson \& Wallace, 2012. Getting Started with Raspberry Pi. Gravenstein Highway North: O’Relly Media.

[4] https://www.raspberrypi.org, diakses 20 Juli 2017, jam 18.05 wib.

[5] Sujani, Herry, 2015, Sensor PIR, Jurnal Edukasi dan Penelitian Informatika (JEPIN), Vol. 1. No.1

[6] Schmidt, A.-D., Peters, F., Lamour, F., Scheel, C., Camtep e, S. A., \& Albay rak, S., 2009, Monitoring Smartp hones for Anomaly Detection. Mobile Networks and Applica tions , 14 (1), 92-106.

[7] Nazaruddin, Safaat., 2011,Pemrograman Aplikasi Mobile Smartphone dan Tablet PC Berbasis Android, Bandung : CV. Informatika.

[8] Bregman D., Korman A., A Universal Implementation Model for the Smart Home, International Journal of Smart Home, Vol.3, No.3, July 2009. 